\title{
Lean Production and Supply Chain Innovation in Baked Foods Supplier to Improve Performance
}

\begin{abstract}
Purpose
Service industries are currently facing an excess of over production that results in extra inventory and waste levels. With the prospect of methods such as lean production, this research seeks to investigate the impacts of lean production methods towards enhanced performance of service based industries through the study of a local baked foods supplier.

Design/methodology/approach

The paper highlights the first stage of research study through current world literature and a critical review as inputs of research findings. The research applies a descriptive research framework within a semi-structured questionnaire survey method which was implemented within three different companies, the baked goods manufacturer, the café purchasing the baked foods products, and the end users, hence covering the overall supply chain cycle and its entities.

\section{Findings}

The research study identified that one of the major challenges facing the baked food company when adopting the lean practices was the lack of commitment from the top management, continuous training and hence, employee engagement measures were necessary towards performance improvement of the organisation.

Originality/value

The research novelty is to develop an early understanding of lean production practices within the baked goods manufacturer and its upstream and downstream stakeholders. This paper would be considered by the food manufacturer companies in order to require their key suppliers to adopt the most common lean tools identified as Just in Time (JIT), Value Steam Mapping (VSP) and the 5S methods.
\end{abstract}

Keywords Supply chain innovation, Sustainability, Lean production, Baked goods supply chain, Performance improvement

Paper type Research paper

\section{Introduction}

Many of the manufacturing and production based businesses are currently experiencing many challenges along with the economic and environmental pressures; they are also addressing the needs to manage and reduce over production and to eliminate and reduce the waste within their organisations. Companies are also facing the huge demands of highly competitive markets that force them to identify and adopt new and innovative production and organisational strategies that allow them to maintain and enhance their overall competitiveness and efficiency levels. The evolution of lean production methods and practices has provided many companies to effectively manage their resources and design and develop better operational and strategic directions towards reducing waste. The success and failures of lean production in manufacturing and other similar industries are very much product focussed.
However, in this aspect food manufacturers and suppliers are considered as ideal participants towards the examination of the adoption of lean practices and methods. It has also been identified that food sector is based on a "very heterogeneous group of products" that has different product characteristics; higher production and manufacturing lead times and with mixed and diverse range of customer requirements and demands for different levels of product quantities at different intervals (Dora et al., 2014).

Due to this heterogeneous environments of the industry and the higher complexities of the types of products, the requirements of various specifications of raw materials and their complex demands within the supply chain, including the changing demands of the customer it makes the production and manufacturing cycles very varied and highly difficult to manage. Similarly, along with the production and manufacturing lead times, the products also is required to be processed, packaged, 
stored and shipped to the user as effectively as possible. This increases the overall lead times for production, packaging, storage and removal. This in turn impacts the manufacturers to balance and reduce the waste and over production aspects as highlighted earlier within the paper.

At present, many service industries are addressing the need of increasing quality of the products while satisfying the customer needs. Addressing the needs of increased global competitions, many companies are focusing towards the improvement of the product quality levels while decreasing their costs and achieving their customer needs. Today, organisation are now adopting Toyota Production Systems (TPS) and applying the Lean philosophy in their settings. They are also using continuous pressure in improving their performance, maintaining competitive advantage in terms of price and service, pressure in improving their profit, customers requesting for the lead- times that are shorter and price reduction (Wheatley, 2005). Considering all the aforementioned points and fulfilling wide variety of customer expectations, addressing the high manufacturing lead times and gaining competitive advantage within the food market, it is required to find out to what extent lean production practices are implemented on organisations, especially within the baked foods supplier industries. Having this in mind, this study has the intention to find out to what extent lean production practices are implemented on organisations. The study aims to provide a detailed comprehensive analysis towards the impacts of lean production practices on companies' performance, while addressing the challenges faced towards the implementation of lean production practices within the organisation.

\section{Literature Review}

The study analyses the current literature to develop understanding of the theories and concepts that plays an important part towards the performance of the organisation. Existing literature provides all the relevant information that specifies and addresses the research objectives and hence this study is structured as following. The research will firstly analyse the understanding of lean production, its goals and strategies for implementation; the influence and acceptance of lean production practices within the service industries; the impact of lean practices towards wider organisational performance and finally the prospect of lean production methods and practices within the food and beverage industries which is real focus of this study.

\subsection{Overview of Lean Production Philosophy}

Research studies have suggested it as a combination of both mass and craft production, and accordingly lean production terminology was used to highlight the mass production systems in early $1990 \mathrm{~s}$ (Womack et al., 1990). The early adopters of lean production principles were the Toyota car manufacturing company that used simple technologies and lower prices automation at the expense of computer technology. Lean production was hence founded and coined as TPS and focused on eliminating waste or any non-value added activities, while addressing the entire production process and making use of different tools and techniques towards reducing waste (Womack et al., 1990; Spear, 1999). Some of these techniques were JIT, VSM, 5S, Kanban (pull systems), Kaizen (continuous improvement), synchronous manufacturing, Pokayoke (Bicheno, 2007; Womack et al., 1990) that led to reduction of stocks while completing on time, that increased their scheduling and delivery performance with proper utilisation of space and resources and thus improving their productivity and quality performance levels (Pavnaskar et al., 2003).

The earliest research focused towards lean production as a philosophy rather than a strategy that focused on set or practices towards reducing waste with the intention to improve performance of any enterprises (Womack et al., 1990). However, modern times have adopted lean production practices to remain more competitive within the global market space (Hosseini Nasab et al., 2012). Previous researchers have tried to describe lean more "theoretically" (Lewis, 2000; Hines et al., 2004; Shah and Ward, 2007) but most of the descriptions were not clear which led to communication problems (Boaden, 1997), implementation issues within enterprises and the problems of having specific objectives (Anderson $\mathrm{el}$ al., 2006). Another study showed that as there are different theoretical approaches about lean production practices, it is difficult to identify its appropriate uses and benefits within the organisation (Parker, 2003). This further implied that as there is a lack of clear description, it would become difficult for some organisations to fully adopt and integrate lean production practices more effectively. To eliminate any uncertainties, Lean production theoretical within this research is defined to as using JIT practice, aiming at using balanced resources, strategies of improving production processes, eliminating waste and using professional technical methods. Nevertheless, it is tough to formulate a definition that has all the Lean production element 
that is in a continuous development. As a result, the definition of today reflects on the present image, which sometime sooner or later will not be effective.

Lean production adoption is considered to be an important method towards managing the operational and strategic gains for reducing waste. Early research within this area has suggested that to achieve and balance continued competitive advantage, organisations required the creation of better production systems to acquire higher product quality that reduces the product design and lead times, thus reducing the waste and over production levels (Womack and Jones, 2006). Lean production practices have been considered as a concept that could be applied at many levels of production which improves and impacts the organisational capabilities (Henderson and Larco, 1999). Due to the global competitions it has increased pressures on manufacturing plants for addressing the importance of operational performance. Lean production can help organisations to resolve and address challenges that are been faced in the current economic climate. Research studies consider it towards gathering and linking inventiveness within any business environments. Another study identified that organisations were able to make use of broader production practices and were finding it challenging to improve and increase the production levels, thus fulfilling the market demands and customer satisfactions (Bicheno, 2007). However, for some organisations the use of modern technologies such as lean production practices has now become more critical practice in order to achieve better performance levels (Emiliani, 2006). These methods have the ability to produce greater quality products in lesser volumes, as well as allowing them to bring these products to market more quickly compared to any mass production products. Hence, it could be said that lean management or lean production is simplified by operating the most efficient and effective organisations with reduced costs and low waste levels while meeting customer demands. The most effective and successful lean producers have identified that lean production practices requires a thorough corporate vision that aims to help all from design to product management, marketing and both internal and external parties of the organisation. With the correct and appropriate procedures, policies and implementation practices, lean organisations enables the use of current data allowing the decision makers to address and achieve the wider organisational goals, thus minimising any over production, inventory levels and reducing waste levels, including shorter lead times while addressing the market demands.
Lean production was first introduced by Toyota, a Japanese automobile firm, after World War 11. Before then, it was called TPS having its single objective to decrease cost and increase production through reducing waste and any non-value adding activity (Womack et al., 1990). In the 1980's, there was an extreme attention on the implementation of lean manufacturing amid the western manufacturers due to the growth of Japanese imports. This resulted to a major apprehension to western producers. The study concept will not be complete if the research discussion towards supply chain management and lean production practices is not highlighted. "Supply Chain Management" is not mentioned. Supply chain (SC) is a system which involves producers or service providers that work together in transforming raw material and distributing through to the consumer. In a modest practice, SC comprise of the organisation, its suppliers, transporters, the warehouse, retailers and the organisation customer. Hence, for SC to be managed properly the following choice need to be considered: Location, production, inventory, transportation, shipment size, moving and planning (Sayed, 2013). The function of the SC in any organisation is to receive and fill the request of customers. This functions in developing new products, marketing, operating, distributing, financing and the customer's service. Hence, the objective of every SC is to maximise the overall value that is generated. The Bullwhip Effect is the magnification of demand variation through the SC. It normally takes place when the demand of a product increases or decreases. The increase in demand is normally blown up when it goes more to the SC. Hence, the Bullwhip Effect need not be looked into so as to avoid offering higher cost or poor service. In measuring the performance of an organisation within a SC, organisation tends to look at its profit, the rate of average the product, and time of response and utilization of capacity. In modern supply chain networks information helps to improve the performance of organisation thereby reducing waste.

The goal of Lean production varies among several authors. Many studies focuses towards internal factors such as increasing the organisation, while others believe that implementing it is for customer's sake. However, the common goal highlighted in studies emphasise to improve quality, stay competitive in current market, and understand the need of customer as well as plan processes that meet customer's requirement and expectations. For this research, the Lean production goal is to reduce the lead-time from order to cash through the elimination of waste from all business processes (Gembutsu, 2015). Lean production goals can 
therefore be divided into (1) Elimination of waste: waste is any unnecessary activities that consumes resources, space or time, and thus add no value to the service or product. (2) The reduction of leadtime: decreasing the time it takes for an activity to finish (start to finish) thus eliminating waste and reducing costs. (3) Reduction of total costs: for cost to be reduced, companies must always produce only what is needed by customers at the right time, the right place and right price. Companies should always avoid overproduction since it is the root cause of all problems and waste.

Lean strategic elements are quite difficult and consist of several elements. Similar research studies identified lean production definition, goals and approaches by categorising Lean into four different ways as (1) Lean as a process of continuous effort or change or "becoming lean"; (2) Lean as a process of becoming lean; (3) Lean as a philosophy of lean thinking or the Toyota way; and (4) Lean as a fixed state or being lean (Pettersen, 2009). The key principles towards Lean Production includes specify value; identify value stream, flow, pull and perfection as shown in figure (1).

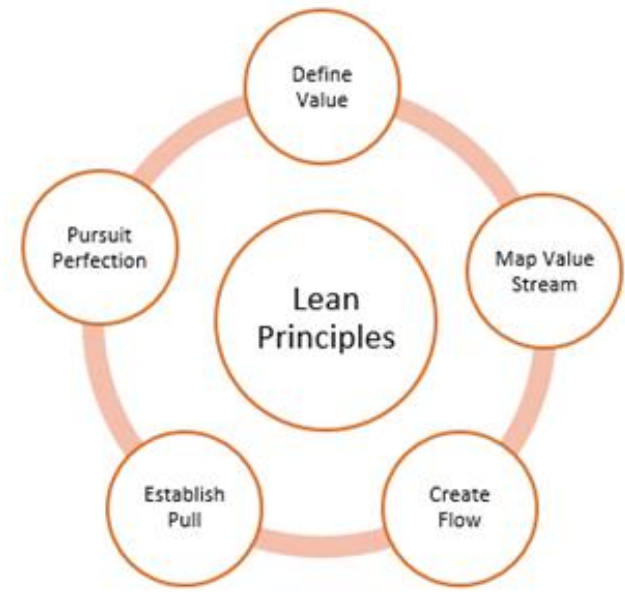

Figure 1. Lean Production Principles (Womack and Jones, 1996)

- Specify value - Value needs to be specified from customer point of view. Manufactures need to know who their customers are. Today, manufacturers make the mistake of producing what they are convenient for them to produce instead of concentrating on producing products that will be valued by customers. Thus, manufacturers are face up to developing product portfolio based on understanding the need of customers, which help to meet the Lean principle of specifying values (Womack and Jones, 1996).

- Identifying the value stream - This Lean concept basically call for organizing processes from materials to final customer based on the customers' perspective, instead of what operators or departments need. Identifying the value stream can be extended to the whole supply chain.

- Flow - Creating flow is a key concept of Lean production that has to do with the workers (people), the processes and even culture. It is used to minimise batches and queues (reducing delays on activities that add value and even reducing the non-value added activities.

- Pull - This concept extremely eliminate over production by concentrating on only what customers require or need. It has to do with reducing time and waste; making the supply chain to be transparent thus reducing uncertainty.

- Seeking perfection - This concept is not all about quality but it include, producing what the customers want, at the right time, at the right price and with minimum waste (Womack and Jones, 1996). This implies that improvement cycle ought to be continuous and it should certainly not end (Melton, 2005).

These five principles were originally developed in manufacturing industries and can still be applied in other industries like the service and food industries. Figure 1 above, shows the five principles that are adapted for baking ingredients. In a study carried out by Belekoukias et al., (2014), whose aim was to find out Lean tools that are used for operational performance, it was found that organisations use five essential techniques such as JIT, Automation (Jidoka), TPM , VSM and Kaizen; for example, Kanban, pull system, pokayoke, current state map, 5S, TQC, TEI, SMED, etc (Belekoukias et al., 2014). They also found that JIT and automation had the strongest impact on operational performance.

\subsection{Lean Production Practices and Service Industries}

At the present time, major service and customer facing industries are aiming towards improving their performance through continuous improvement techniques to remain competitive in the market place while addressing the demands from the customers. In order to fulfil this the companies are required to adopt better production practices and strategies as a whole organisation wide strategy.

The key focus for lean production practices is towards the elimination of waste, and includes all the activities that do not add any value to the organisation or the customer. This focus is very 
much addressed by each individual company and not passed on to the customer, hence it is very important for companies to address and reduce waste. The follow Figure 2 represents the seven different wastes within the lean philosophy as illustrated in earlier research by Taiicho Ohno within its "lean philosophy" (Ohno, 1988).

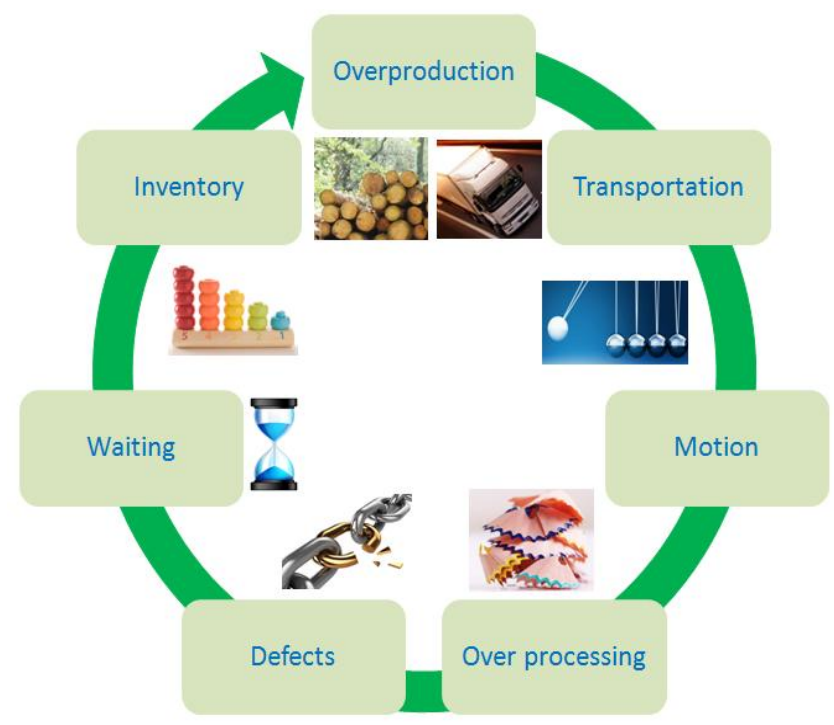

Figure 2. The Seven Deadly Wastes of Lean Philosophy Philosophy (Ohno, 1988)

Overproduction - this is the most critical among the seven types of wastes and is the root of many problems. Overproduction is referred to as producing in advance before demand (too early), too much or even just in case; it discourages the smooth flow of goods, causing inventory to be high and extended storage time and cost. Overproduction also brings about too much work-in-queue, work-inprocess inventories and thus obstructs communication.

Transportation -This is believed to be a waste because customers do not pay for their goods to be moved around the factor thus moving materials from one place to another is waste because it does not add value to the finished good rather it raises the lead time of production, consumes the capacity of resource and the floor space.

Motion - this is the motion of movement of workers to carry out activities including reaching, stretching, walking distances to collect and deliver materials, including information sharing. Unnecessary movements by workers covers business's ergonomics production thus lead to producing lower quality product.

Over processing - often linked towards taking inappropriate steps that are not required within the production processes which are not in the requirements of the customers. It is using less quality machines, unqualified people or processes during a production. Hence, it is ideal to always use the right machine in producing the right product. In the factory, the main cause of over processing is due to workers wrong attitude.

Defects - this refers towards the production of faculty or imperfect products which requires extra inspection and quality controls, including reworking and fixing of the defects. It is a constituent that is unacceptable to the customer with regards to quality standard. Defect affect business direct costs, it makes customers not to have the confident in company's products and it causes delay during production hence lead to extra tasks and increases production lead time.

Waiting - this takes place when time is not appropriately managed effectively and utilised well enough, if the equipment, resources, materials or workers are not able to add value to any and every aspects of the production lines. Waiting occurs as a result of maintenance, changeover, setup, inspection and other quality related problems. It is the enemy of smooth flow thus affect production, prolong lead time and causes unnecessary bottlenecks.

Inventory - any excess levels of raw materials and components, either semi or finished products that requires additional facilitation and storage requirements by the company. Unnecessary inventories lead time, ties up money that could be used to improve processes, prevents fast identification of problems as well as separating process steps and reduces communication.

The mentioned main waste types are only the obvious part of the wastes within the supply chain and manufacturing processes and there could be many other wastes referred to "hidden wastes" (Hines et al., 2004) that need to be identified. A research study highlights the eight group of deadly waste that would be the fact that the companies do not usually apply the staff potentials; hence their creative comments and ideas would not be used despite of their benefits towards process improvements (Carreira, 2005). The author also classifies the setup and changeover costs as process wastes as they are highly sensitive processes and do not benefit the organisation and final consumers. It can be noted that sometimes the non-value added activities such as financial inspections are necessary as part of the process that also add value to the company, hence should not be eliminated (Carreira, 2005). Eliminating the wastes, we need to find the root causes of the wastes rather than only the resulted symptoms (Melton, 2005). According to the Lean Enterprise Research Centre (LERC), it is stated that only $5 \%$ of all the activities add value, 
while $35 \%$ of them are essential for non-value added activities and surprisingly, $60 \%$ of all add no value to the organisation and customers at all (Melton, 2005). In this case, the waste minimisation techniques would be critical in terms of manufacturing advancements and hence, it is required for waste and value to be identified, the knowledge management strategies to be developed and to realise that it is the personnel's job to operate for continuous improvement and the sustainability of the business (Melton, 2005).

\subsection{Impact of Lean Practices on Organisational Performance}

It has been seen through similar research studies that lean production practices have been mainly developed and adopted by companies that were interested towards improving performance levels both locally and at global market levels. However, while evaluating the impact on performance levels within the organisations, many research studies have described this into "leanness". For instance, similar studies used the model to measure the degree of leanness in UK agricultural machining sector (Forrester et al., 2010); another study used the model in determining the level of leanness by using different attributes of lean such as Kaizen, JIT and TQM (Bayou and Korvin, 2008). Further research helped towards examining the impact of exact influences leanness that it had towards manufacturing systems. From this study, it had proved that the components that are most vital towards the leanness consisted of imperfections, cost, lead times and value (Anvari et al., 2013). Finally, another study established the model which helped measuring the level of leanness based upon thirty criteria and using fuzzy logic approaches to relate the connection of leanness to that of organisational performance (Vinodh and Vimal, 2012).

In a study carried by Dora et al. (2013), whose aim was to analyse how lean manufacturing (all approaches) is used and the impact it has on operational performance, it was found that when Lean is implemented in organisation, it improves productivity and quality. Another research conducted by Taj and Morosan (2011), it was found out that Lean practice helps organisations (Chinese manufacturing companies) to improve their quality, flexibility and flow performance. This implies that with Lean tools organisations will produce product which are of high quality in a more flexible way. However, for the performance to be flexible, the organisations supply chain, human resources and the production system design need to be monitored greatly. Rahman et al. (2010), states within their research that JIT, waste minimisation and flow management have major influence on the operational performance on organisation. Rahman et al., (2010) further states, that for large companies, JIT has a greater significance compared to SMEs. Bhasin (2012) also depicted the relevance of Lean in improving organisations performance. A further point to consider when using lean tool on performance of organisation is how it is been adopted. Cua (2006) indicates that Lean tools such as JIT, TPM, have positive and important consequence on organisations delivery, cost, quality and flexibility. This seems to indicate a connection between Lean tools and organisation performance. Companies are already making use of this Lean tool in improving their responsiveness and effectiveness (Bortolotti et al., 2013). This implies that Lean principle help organisations to be successful in present economy thus improving their profitability. With Lean tools, managers are also able to obtain reviews about their effectiveness. This indicates that Lean practice have a general impact on the overall performance of the organisation.

The most common challenge in implementing Lean production is how it can be maintained. Lean production is a continuous process, thus requires more commitment from workers. While reviewing the literature, other challenges faced in implementing Lean were mentioned repeatedly, they include: Lack of awareness or understanding, technological problems, supply chain problems, customers uncertainties in demand, lack of top management commitment and support, pressure from customers, lack of common vision, lack of communication, educational issues, financial issue, (Sarhan and Fox, 2013; Abdullah et al., 2009). Other challenges faced when in implementing Lean production include; logistic problem, poor organisation, and absence of delegation to improve the flow of work.

Another study uses resource-based view (RBV) towards examining the relationship between resources (i.e. manufacturing technologies and lean practices) and operational performance. The resource-based view method argues that business organisations, including those within same industry and same operational environment are heterogeneous in their resources and hence explains their competitiveness and performance differences (Khanchanapong et al., 2014). As it is evident from other research studies that the benefits of lean production approaches are difficult to measure, an alternative method called the balanced scorecard system that aims to support the change strategies allowing the managers to specifically focus towards the linkages and operational efficiencies within their 
organisations (Bhasin, 2008). The most effective tool to measure the lean progress is that of the total life cycle time and hence, the scorecard approach is considered to be the most appropriate practice within the case. It is also evident from the research that more than $60 \%$ of firms are using the balanced scorecard methods already within their organisations (Kaplan and Norton, 2005). It is also discussed that scorecard is not the ideal approach towards defining the appropriate strategies for lean and hence, it is rightfully the responsibility of the manager to handle the measurement considerations through the help of advanced software programmes.

According to a study, the authors used dynamic multi-dimensional performance (DMP) approach in order to enable organisations to measure whether the implementation of lean practices are successful or not, due to the fact that less than $10 \%$ of all the UK enterprises find lean approaches as the effective pathways towards their organisational success (Bhasin, 2008). The five major parameters developed by DMP is comprising of financial measures, customer/market measures, process measures, stakeholders development measures and future prospects measures. The mentioned factors would help the companies to track their organisational performance resulted by lean progress in both short term and long terms, i.e. the financial dimension refers to the short term and the future represents the long term results (Bhasin, 2008).

It is worth to analyse the application of lean manufacturing influences on organisational performance of the SMEs, especially in the food processing sector which in known as the principal manufacturing sector in Europe with more than five hundred million consumers (Dora et al., 2013) which has recently raised the lean practices due to tight competitions and customers pressures (Mahalik and Nambiar, 2010). However, some studies state that due to the short shelf-life, diverse raw materials, seasonality and different harvesting conditions the lean practices would have low influences on the unique characteristics of this sector (Luning et al., 2002). The most critical success factors of lean practices in food industry that also contributes to their operational performance are mentioned as the workforce expertise, in-house skills and the organisational culture (Dora et al., 2013).

\subsection{The Gaps in Lean Production within Food and Beverage Industries}

Research studies have provided an insight on the adoption of lean production practices within food industry in general and more specifically that the small food manufacturers and suppliers are very limited, compared to that of large product based manufacturing environments. However, there is a gap within literature due to the developments within the proper research studies and the applicability of lean production practices in food industry. Some of the early research evidence within this area suggests that the application and findings from lean production methods within the food industry is a very much exploratory topic and there are no conclusive findings within the academic and research fields. Most of the evidence based research studies are focussing towards the use of case studies and lacks the advantage of a more systematic based literature evidences (Dora et al., 2014). Many of these studies are focussing more towards the use and application of lean models and tools within the food manufacturing companies, with little or no evidence towards wider lean production practices such as those highlighted within this research and discussed later in Table I (Shah et al., 2017).

At the present time, the food and beverage industries are dealing with the challenge of not being able to identify waste and thus meeting the market price. According to EuroCommerce, as representor of national federations and companies in retail and wholesale sector from 31 European countries, recent data from the EU-funded FUSIONS projects indicate that $53 \%$ of food waste is generated in households, $19 \%$ in food processing, $12 \%$ in food service, $11 \%$ in production, and $5 \%$ of in wholesale and retail (EuroCommerce, 2017). Overcoming the food waste, the retailers are trying to prevent food waste from happening in the first place and building a sustainable supply chain with the aid of government well-designed legislations along with the retailers and wholesalers smart volunteer actions (EuroCommerce, 2017). Many of the food retail companies in UK such as $M \& S$ and Tesco are nowadays working with the national associations in order to apply the initiatives for waste management within the whole supply chain including their shops in addition to consumer engagement and support of local community (EuroCommerce, 2017. However, through the inclusion of lean production methods and practices, the food and beverage industries will be able to identify and eliminate the $11 \%$ waste of production through continuous improvement methods. 
Table I. Lean production tools (Shah et al., 2017)

\begin{tabular}{|c|c|c|}
\hline Tool & Description & Reference \\
\hline $\begin{array}{c}\text { Value } \\
\text { Stream } \\
\text { Mapping }\end{array}$ & $\begin{array}{l}\text { VSM is a tool used in } \\
\text { designing, analysing or } \\
\text { mapping out all actions (both } \\
\text { value and non-value) in the } \\
\text { production process by } \\
\text { examining the flow of raw } \\
\text { material from its supplier to end } \\
\text { customers. Research studies } \\
\text { suggest by using VSM, } \\
\text { organisation can decrease their } \\
\text { lead-time and production time, } \\
\text { smoothing their production, } \\
\text { decrease waste and improve the } \\
\text { quality of a product. It reduce } \\
\text { operational cost, increase } \\
\text { flexibility and helps } \\
\text { organisations to meet the } \\
\text { demand of their customers. }\end{array}$ & $\begin{array}{c}\text { Kanyanya } \\
\text { (2013); } \\
\text { Goriwondo } \\
\text { et al. }(2011)\end{array}$ \\
\hline$J I T$ & $\begin{array}{l}\text { This is a process which states } \\
\text { that an organisation should } \\
\text { produce the right product at the } \\
\text { right time. Research studies } \\
\text { also state that by using JIT, } \\
\text { organisation will reduce } \\
\text { production cost, inventory, } \\
\text { changeover time, set up time } \\
\text { and likely waste. }\end{array}$ & $\begin{array}{l}\text { Wamack } \\
\text { and Jones } \\
\text { (2003); } \\
\text { Kanyanya } \\
\text { (2013) }\end{array}$ \\
\hline Pokayoke & $\begin{array}{l}\text { This is referred to a tool which } \\
\text { helps staff to avoid errors. The } \\
\text { purpose of pokayoke is to } \\
\text { eliminate product defects by } \\
\text { preventing, correcting or } \\
\text { drawing attention to human } \\
\text { errors. The Lean concept is } \\
\text { criticized in the literature from } \\
\text { the perspective of the } \\
\text { personnel, because this side is } \\
\text { less known, focusing primarily } \\
\text { on techniques for improving the } \\
\text { performance of the system. }\end{array}$ & $\begin{array}{c}\text { Dudek- } \\
\text { Burlikowska } \\
\text { and } \\
\text { Szewieczek } \\
\text { (2009) }\end{array}$ \\
\hline Kanban & $\begin{array}{l}\text { The Kanban is a stock } \\
\text { controlling system which is } \\
\text { achieved by the FIFO method. } \\
\text { This is an effective tool that } \\
\text { contributes to the functioning } \\
\text { of the whole production } \\
\text { process. According to Kanban } \\
\text { system has many advantages } \\
\text { over computer technologies, } \\
\text { such as; reduced cost of } \\
\text { information processing, it is } \\
\text { easy to obtain and transmit } \\
\text { information in a dynamic } \\
\text { environment; the demand for } \\
\text { materials is judiciously sized. }\end{array}$ & $\begin{array}{c}\text { Sugimori et } \\
\text { al. (1977); } \\
\text { Kanyanya, } \\
\text { (2013) }\end{array}$ \\
\hline
\end{tabular}

\section{Research Methodology}

The research combines multiple research methods and approaches, including critical review of literature, case study analysis of baked food supplier and through expert interviews of the service company facilitating the supply of the products to the customers. The literature review provided the researchers with an insight of the research topic and the research gaps identified within the use of lean production approaches within foods and beverage based service industries. This section presents the details of the research approach and strategy adopted within this paper.

\subsection{Research Strategies and Approaches}

Evidence from the research has suggested that methodology enables researchers to address the question of how, what and why through collection, analysis and interpretation of the data and findings in a structured manner. The research was initiated from theoretical analysis through the cycle of data collection and qualitative modelling through the help of case studies using semi-structured questionnaires and expert interviews. The factors and parameters for this study were generated from the literature studies and that of the relationship with the overall framework and model of the research study. The empirical approaches also included qualitative research methods implemented to develop further understanding and insight of the topic. There are number of research strategies that could be used to address research objectives, however from the nature and purpose of this study the use of questionnaire had been selected. The target population for the study were derived from the scope of the research topic and through understanding developed from the literature studies. The local baked foods supplier (company X) was considered as the target population, along with managers of local university café and the end users as the customers within the supply chain cycle.

\subsection{Data Collection Methods}

Research studies suggest that a suitable data collection method highly impacts on the success of any research studies (Malhotra and Birks, 2003). In any business research studies, the primary and secondary data allows the researchers to collect the data that allows fulfilling the research objectives more efficiently and effectively. The secondary data allows the researchers to reduce time and resources and hence is always analysed at the start, while the primary data provides the researchers with more collective representation of the findings, which the secondary data may not be able to address all the aspects of the research studies. Hence, this research implemented both the primary and secondary data within the study. Through the data collection methods identification, the researchers then used two types of data collection modes as quantitative and qualitative (through expert interviews). This 
was conducted through; firstly data collected through the end users (i.e. customers) and allowed the researchers to identify early within the research towards the satisfaction levels of the customers/students using the products. Secondly, the interviews with managers from the café allowed the understanding of the business and supply chain frameworks, and the frequency and lead times of the products within the environment. And finally, data was also collected to the local baked foods supplier as the main point of the research study, which enabled the researchers to provide the linkage of the lean production practices within the supply chain context.

\subsection{Research Collection and Questionnaire Design}

Following up from the different research methods identified and the use of semi-structure questionnaire and expert interviews to collect the data, the researchers then started the design and development of suitable questionnaire for the research. The aim of reducing any biasness within the research, the researchers considered the issues such as wording, appearance and the categorisation of the variables within each of the questions as suggested from previous research studies (Berdie and Anderson, 1986). The design of the questionnaire requires a thorough understanding of the research topic, and through the support of the literature review conducted within the research, the survey questions were based on the overall research framework. Similarly, another factor which was considered was that of the sequence of the questions within the questionnaire and that the order in which the perception of the respondent were captured appropriately. This was carried out by asking generic questions towards the engagement of the respondents to that of more mixed questions which prevented from the key research objectives clearly represented within the study. The design of the physical questionnaire plays an important role within the overall design and could affect the rate of response, so it is equally important for the questionnaire to be of good quality to allow the responses to be captured satisfactorily (Fanning, 2005). Hence, consideration were taken when the questionnaire were produced including factors such as layout, quality and clarity of the questions presented to the respondent, including the use of simple and plain English language. The questions were measured using the five point Likert scale method that range from 'excellent to poor', 'highly satisfied to highly dissatisfied', 'always to never', 'strongly agree to strongly disagree', and 'very large extent to very small extent' which was adopted from earlier research studies towards research methods and questionnaire design techniques (Sánchez et al., 2014). The three different types of research surveys that were conducted within this study are as shown in Figure 3.

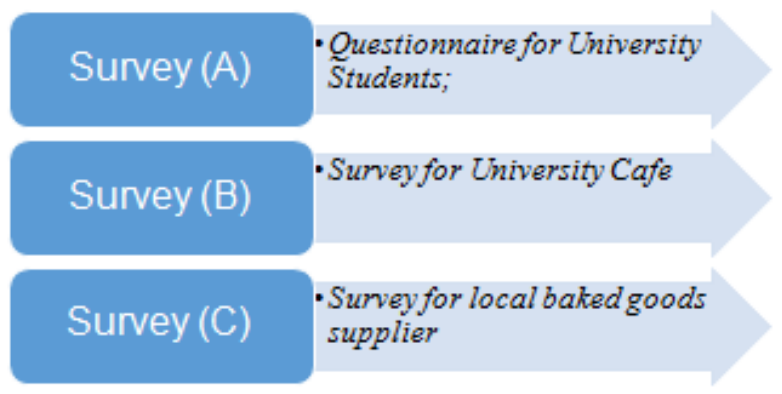

Figure 3. Research Survey Types

\section{Survey A - University Students}

The first five questions (Questions 1-5) in this questionnaire were basically demographic and totally unidentified questions this made sure that the respondent answered the questions without having a fear of identity being revealed. In question six to seven, the respondents were simply asked how often they buy baked goods and what product they prefer to buy on campus respectively. The eight questions basically asked the survey respondents how much they spend on baked goods while on campus weekly. A total of 50 students participated in the study, whereas $62 \%$ participants were female and $38 \%$ male; among it $34 \%$ were postgraduate students and $66 \%$ were undergraduate students. In addition, $78 \%$ of respondents who purchased products from cafe were students not residing on the campus.

Table II. Questionnaire for university students

\begin{tabular}{|c|l|}
\hline No & \multicolumn{1}{|c|}{ Question } \\
\hline 1 & Demographic details (Age, Gender) \\
\hline 2 & Student Details (level of study, type of programme) \\
\hline 3 & On/Off Site Living Accommodation \\
\hline 4 & Frequency of Purchasing "baked goods products" \\
\hline 5 & $\begin{array}{l}\text { Types of Baked Goods products (choice of } \\
\text { multiples) }\end{array}$ \\
\hline 6 & Average Weekly Spending \\
\hline 7 & $\begin{array}{l}\text { Ranking unique features of baked goods on campus } \\
\text { (factors - price, quality, taste, availability, } \\
\text { freshness etc.) }\end{array}$ \\
\hline 8 & $\begin{array}{l}\text { Customer/Product Satisfaction Levels (Likert scale } \\
1-5)\end{array}$ \\
\hline
\end{tabular}

Again, in question nine, the respondents were asked to rank the features of baked goods on campus. This question basically used a Likert scale with choices ranging from 'poor', 'average', 'good', 'very good' and 'excellent'. Finally, the last question asked the respondents how satisfied they are on baked goods that are sold on campus. 


\section{Survey B - University Cafe}

The survey package consists of demographic questions, list of interview questions basically open ended questions and a short guide to answering the questions stating the information that the researcher would need to deduct from the feedback. The last page in the survey had a space for additional comments. This was provided just in case the respondent wished to give further feedback about their suppliers. Questions asked during the interview are as shown below in Table III. A total of 5 interviews were conducted with four managers and one team leader. A combined 25 years of managerial experience was observed between the four mangers interviewed.

Table III. Questionnaire for university café outlet

\begin{tabular}{|c|l|}
\hline $\begin{array}{c}\mathbf{N} \\
\mathbf{o}\end{array}$ & \multicolumn{1}{|c|}{ Question } \\
\hline 1 & Demographic details (Age, Gender) and Position \\
\hline 2 & $\begin{array}{l}\text { Background information (background, experience, } \\
\text { qualifications }\end{array}$ \\
\hline 3 & $\begin{array}{l}\text { Who are your local "baked goods supplier" for your } \\
\text { outlet }\end{array}$ \\
\hline 4 & What is the preferred mode of communication \\
\hline 5 & $\begin{array}{l}\text { Do you have other alternative suppliers that you could get } \\
\text { goods from? If Yes, what are the factors for selection? }\end{array}$ \\
\hline 6 & $\begin{array}{l}\text { Do you experience efficient communication and } \\
\text { information exchange between you company and the } \\
\text { suppliers? If No, please give reasons. }\end{array}$ \\
\hline 7 & $\begin{array}{l}\text { Key Issues and Challenges from your supplier (response } \\
\text { time, quality, price, consistency, other) }\end{array}$ \\
\hline 8 & Frequency of placing orders with the supplier \\
\hline 9 & $\begin{array}{l}\text { Do you regularly collect feedback and suggestions from } \\
\text { your customers about the products (i.e. students and staff) }\end{array}$ \\
\hline
\end{tabular}

\section{Survey C - Local Baked Goods Supplier}

The Company $\mathrm{X}$ questionnaire consisted of five sections and in total 8 questions. The first sections (Q 1- 3) were general respondent information and completely anonymous questions as this will allow respondents to freely respond without any fear. The second section (Q4) was to find out what lean production practise they use, the third section (Q5) consisted of different questions that corresponded to the indicators within the framework. The fourth section (Q6) was to know what extent has the implementation of Lean production practice impacted their organisation performance. The fifth section (Q7) was to know the challenges their organisations face while implementing Lean production practice. A total of 18 questionnaires were returned from the local foods supplier, out of which three incomplete surveys were removed, making a total of 15 surveys used for the analysis for this study.
Table IV. Questionnaire for local supplier

\begin{tabular}{|c|l|}
\hline No & \multicolumn{1}{|c|}{ Question } \\
\hline 1 & Demographic details (Age, Gender) \\
\hline 2 & $\begin{array}{l}\text { Background information (background, experience, } \\
\text { qualifications }\end{array}$ \\
\hline 3 & $\begin{array}{l}\text { Are your staffs aware and adopt "Lean Production } \\
\text { Practices" within your organisation? }\end{array}$ \\
\hline 4 & $\begin{array}{l}\text { Which of the following lean production practices are } \\
\text { utilised within your company (lean tools, value } \\
\text { stream mapping, JIT, Jidoka-Automation, Pokayoke, } \\
\text { Kanban, Kaizen, Five Ss) (always - frequency-often } \\
\text {-sometimes - never) }\end{array}$ \\
\hline 5 & $\begin{array}{l}\text { What waste do lean production practices eradicate in } \\
\text { your organisation (lean tools, value stream mapping, } \\
\text { IIT, Jidoka-Automation, Pokayoke, Kanban, Kaizen, } \\
\text { Five Ss) (Likert Scale) }\end{array}$ \\
\hline 6 & $\begin{array}{l}\text { To what extent has the implementation of lean } \\
\text { production practices impacted towards your } \\
\text { organisational performance (multiple factors); }\end{array}$ \\
\hline 7 & $\begin{array}{l}\text { What challenges does your organisation faces with } \\
\text { the implementation of lean practices? (Management } \\
\text { commitment, training, data accuracy, financial, } \\
\text { technical expertise, regulations and policies, etc.) }\end{array}$ \\
\hline
\end{tabular}

\subsection{Research Questionnaire Analysis}

Qualitative research methods allows the generation of large amounts of data through the use of semistructured interviews. Therefore, the main focus of the method and that of data analysis should be towards the reduction of data sets. Research studies states that it is important to acknowledge that irrespective to the kind of research carried out, either qualitative or quantitative, there is always going to be a degree of subjectivity that will exist within the research design (Rabiee, 2004). Descriptive information similar to the data collected should through the process of content analysis. For this purpose, the researchers have adopted the method of content analysis within this research study. Content analysis is very simply the process where the key themes are identified on the basis of the responses received through the analysis. This method is ideal when the research study presents the outcomes of a combination of open ended questions as well and multiple subjective analyses. Content analysis also provides code groups of words that are unique within the data collection and further allows them to be analysed into different sections within the study.

\section{Case Study Analysis}

The food and beverage industry is one of the world largest marketplace that serves about 100million meals per day with the standard of fresh, quality, nutritious and traceability. The industry is a major contributor to the growth of all economies and has also historically witnessed consistent growth. In the UK, the industry is a dynamic industry that 
produces some of the world's best brand. According to Webb (2010), the food and beverage industry is defined to be its output of product that helps in satisfying the different customers demand. This industry comprises of all companies that are involved in processing raw food materials, packaging, and distributing them. This includes fresh, prepared foods, bakery, packaged foods, and alcoholic and non-alcoholic beverages. The food and beverage industry is a basis of economic growth and wealth around the world (Romsdal et al., 2011). It plays a distinctive role in expending the opportunity of the economy because it is common to health and human life.

The food and beverage industry comprises of numerous aspects, which may affect it daily operations. It includes competitors, suppliers and consumers. It has spread into different areas such as universities cafe, hospitals, cafe, hotel, industrial cafe and restaurants etc. The main aim of this industry is to satisfy customers economic, social, and psychological and convenience needs by making good fresh food available especially when needed. The products need to be delivered fast to both the retailers and customers. Quality of the product is a vital factor in the food and beverage industry as this will help in retaining the loyalty of customer. Hence, due to customer's uncertainty in demand, there is needed to offer different range of products in order to meet the demand of customers in this present fierce competitive market. The food and beverage supply chain (SC), comprise of widespread of diverse products and businesses that operate in diverse marketplaces and sell different product such as agriculture, transport, energy and chemicals. The governing framework is been affected by the food and beverage SC at all stages from the agricultural down to the retailing sector. In the agricultural sector, for example, about two thirds of national outputs in the UK are used for production of food and beverage (FDF, 2010).

\subsection{Company X Overview}

The local university cafe outlets have many suppliers that supply baked goods materials that are needed in the entire campus. The cafe strives to use only the best ingredient in the market in order to create quality products as ingredient plays an important role to baking mouth-watering delicious food. The production of bakery products consists of a few vital ingredients, primarily, sugar, and wheat flour. This ingredient helps to enhance the quality of the final product.

\subsection{The Supply Chain Environment}

Supply Chain Management (SCM) is a network created between various businesses that produce, handle or distribute precise product. It comprises the different steps taken for goods/ services to reach its customers from the supplier. Research shows that SCM uses strategies implemented by businesses to aid in coordinating the activities of their SC while improving their performance thus minimizing costs, improving the performance of customers service and fasting response time (Arshinder et al., 2011). The value a SC generates is the difference between what the final product is worth to the customer and the cost the supply chain incurs in the filling the request of the customers. An effective SC needs to have the following objectives: quality, speed, dependability, flexibility, and cost. SC of Company X operations may experience some issues such as receiving the ingredients on time, human error, communication problem and quality problem etc, hence, there is need to understand the SC drivers. Drivers of the SC determine the SC performance in terms of responsiveness and efficiency. SC has four drivers that help in its performance. They include:

- Inventory: This can be defined as the raw material, WIP and finished goods within a SC. Inventory is a key SC driver because changing inventory policies can dramatically alter the SC's efficiency and responsiveness.

- Transportation: This entails the movement of inventory from one point to another in the SC. Transportation can take the form of many combinations of modes and routes, each with its own performance characteristics.

- Facilities: This is referred to the place in the SC network where inventory is stored, assembled, or fabricated. The two main types of facilities are production site and storage sites.

- Information: This consists of data and analysis regarding inventory, transportation, facilities and customers throughout the $\mathrm{SC}$ as it directly affects each of the other drivers. Information plays a vital role in operating a SC.

The three main sectors in the SC of company X are the agricultural, food processing and the distribution (wholesaler and retail) sector. Agricultural products go through different processes before they are sold as final products to customers. Firstly, in the agricultural sector, the activities have done include the production of crops. Firms in this sector basically sell the output of their product to the food processing sector and may also sell directly to retailers, final consumers or even to alternative 
markets. Secondly, the food processing sector which is actual diverse and consist of different activities such as refining (sugar), milling (flour) or slaughtering (livestock). Different inputs are processed in successive stages and to different degrees, packaged and dispatched to customers (e.g. distributors, food service). Finally, the distribution sector (specifically retail) which is the principal outlet for food products and, also the SC final link, which interacts with final consumers directly, is processed. While the sector's main activity is the sale of products, in doing so, retailers may also carry out services for food manufacturers, such as promotional activities. Goods may be transferred directly between the firm that are involved in production or sales to customers via wholesalers. During this process cost such as raw material, labour, transportation, storage or even logistics are incurred.

\section{Data Collection and Analysis}

This chapter shows the data collected and results of the analysis, which include demographic characteristics of the sample (questionnaire of university students and their baked goods suppliers, and interviews conducted), the different research criteria factor (Table V), descriptive statistics of the variables, and measurement. The criteria are ordered accordingly to aid as a guide in analysing the data in this chapter; however when discussing the result, each individual criterion will be analysed separately. The challenges organisation faced while implementing Lean practices will also be analysed separately.

Table V. Framework factors key measurement criteria.

\begin{tabular}{|l|l|}
\hline Factor & Criteria \\
\hline Quality & $\begin{array}{l}\text { JIT }- \text { VSM - Pokayoke/Automation - } \\
\text { Kaizen }-5 S-\text { Kanban }\end{array}$ \\
\hline Speed & $\begin{array}{l}\text { JIT - VSM - Pokayoke/Automation - } \\
\text { Kaizen - TPM - 5S - Kanban }\end{array}$ \\
\hline \multirow{2}{*}{ Dependability } & $\begin{array}{l}\text { JIT - VSM - Pokayoke/Automation - } \\
\text { Kaizen - 5S - Kanban }\end{array}$ \\
\hline \multirow{2}{*}{ Flexibility } & $\begin{array}{l}\text { JIT - VSM - Pokayoke/Automation - } \\
\text { Kaizen - TPM - 5S - Kanban }\end{array}$ \\
\hline Cost & $\begin{array}{l}\text { JIT - VSM - Pokayoke/Automation - } \\
\text { Kaizen - 5S - Kanban }\end{array}$ \\
\hline
\end{tabular}

Demographic questions were incorporated in the survey in order to gain some basic background information of students at a local university. A total of 50 students participated in the study. Approximately $62 \%$ of the participants were female and $38 \%$ were male. Among them, $62 \%$ ranged in age from 18 to 22 years old. $66 \%$ of the participants are undergraduate students while $34 \%$ are postgraduate students. From the analysis, among the 50 respondents, majority (78\%) respondents that buy baked goods in campus cafe outlets do not live on campus. Figure 4 below shows how often students buy baked goods from campus outlet. From this Figure it is clear that most students (40\%) buy baked goods on campus daily.

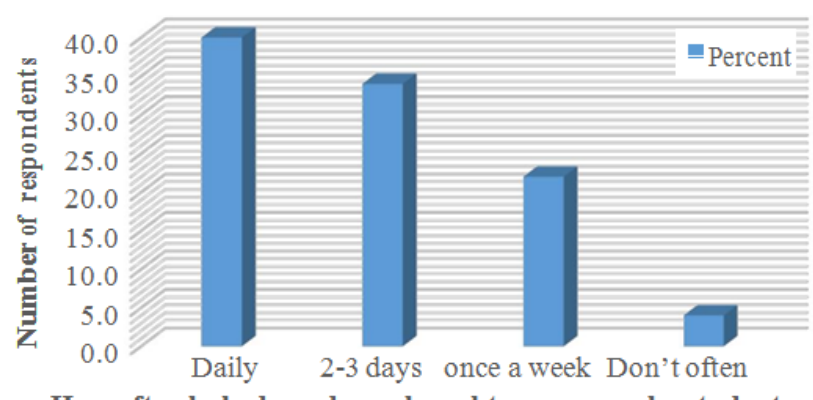

How often baked goods are bought on campus by students

Figure 4. Analysis of Number of Sales of Baked Goods

As shown (figure 5) towards the number of students (end users) spending on the baked food within the campus. From the analysis it is shown below that $58 \%$ of the respondents spend less than $£ 10$ buying baked goods on campus, while $42 \%$ spend from $£ 10$ to $£ 30$ in buying baked goods on campus per week.

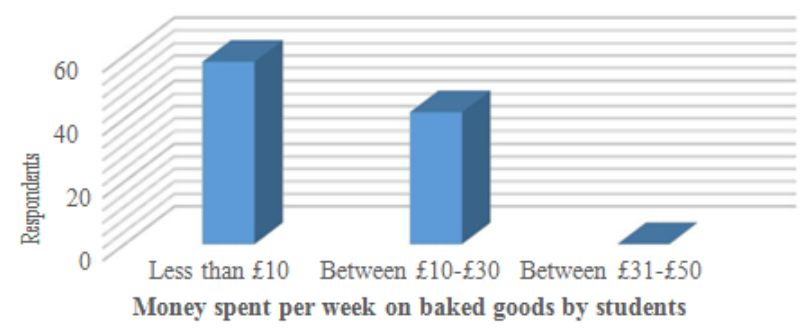

Figure 5. Analysis of Amount Spend Each Week

The analysis towards how respondents ranked the baked food that was sold on campus is shown in Figure 6. Based on the feature price, $50 \%$ believed it to be in average, while only $4 \%$ believed to be excellent, including $4 \%$ thought of it to have feature quality as excellent..

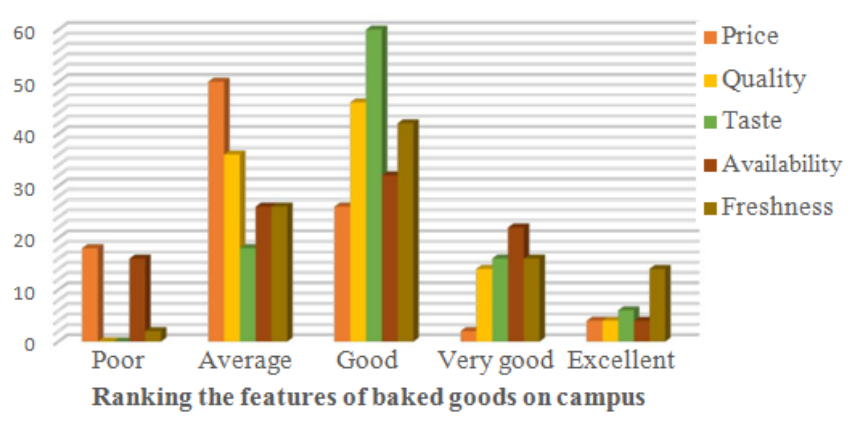

Figure 6. Analysis of Ranking of Features of Products 
With regards to the feature taste which 60\% identified as good, and for feature availability where $4 \%$ rated it as excellent, and for freshness only $2 \%$ thought it to be of poor rank

\subsection{Utilisation of Lean Practices in Company $X$}

The analysis and the findings from Figure 7 demonstrates that $73.3 \%$ of respondents indicated the use of VSM and JIT as always, whereas $73.3 \%$ has used $5 \mathrm{~S}$ which matched to the earlier research studies highlighting towards this (Belekoukias et al, 2014) on the use of JIT, VSM and 5S as the most frequently used methods by organisations towards improving the operational performance levels. Some of the other tools and methods used were TPM, Kaizen, Pokayoke, Jidoka, and Kanban, which although were not frequently used, however our research studies has still examined their usage within the study.

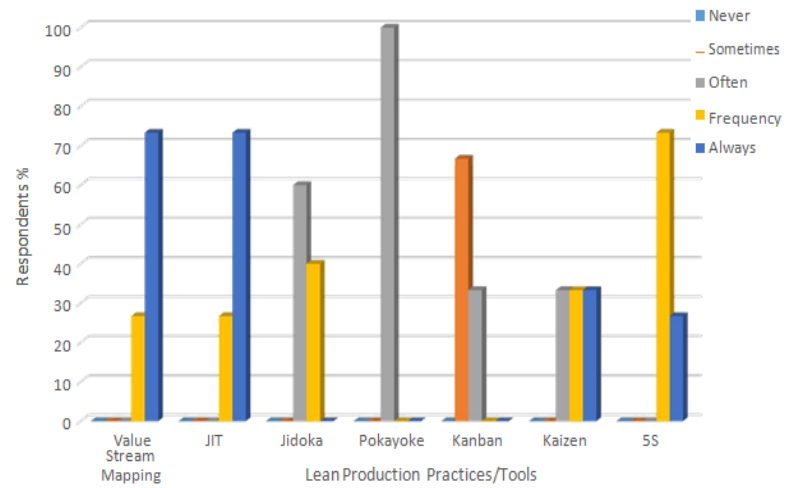

Figure 7. Lean Production Practices/Tools (Shah et al., 2017)

\subsection{Lean Practices Impact on Performance}

The target population were asked about the key attributes of lean production practices and that of the tools such as VSM, JIT, 5S, Kaizen, Pokayoke, Jidoka and Kanban within their respective organisation. This question corresponded to the indicators within the research framework and as illustrated within the next part of the analysis in the paper.

\section{VSM}

From the results shown (Table VI) towards the frequency analysis of VSM method, it has also been used to design, map out or analyse all action and has a positive impact on the performance of the organisation.
Table VI. Frequency Analysis for Criterion VSM (Shah et al., 2017)

\begin{tabular}{|c|c|c|c|c|c|c|c|}
\hline Factor & VSM & \begin{tabular}{|l} 
Strongly \\
agree
\end{tabular} & Agree & Undecided & Disagree & \begin{tabular}{|l} 
Strongly \\
disagree
\end{tabular} & Mean \\
\hline \multirow{5}{*}{$\begin{array}{l}\text { Quality, speed, } \\
\text { dependability, } \\
\text { flexibility and cost }\end{array}$} & Wastereduction & $40 \%$ & $60 \%$ & $0 \%$ & $0 \%$ & $0 \%$ & 4.40 \\
\hline & $\begin{array}{l}\text { Reduced } \\
\text { production time }\end{array}$ & $40 \%$ & $60 \%$ & $0 \%$ & $0 \%$ & $0 \%$ & 4.40 \\
\hline & Reduced lead time & $26.7 \%$ & $73.3 \%$ & $0 \%$ & $0 \%$ & $0 \%$ & 4.27 \\
\hline & $\begin{array}{l}\text { Enhanced quality } \\
\text { of output }\end{array}$ & $26.7 \%$ & $73.3 \%$ & $0 \%$ & $0 \%$ & $0 \%$ & 4.27 \\
\hline & $\begin{array}{l}\text { Production } \\
\text { smoothing }\end{array}$ & $66.7 \%$ & $0 \%$ & $33.3 \%$ & $0 \%$ & $0 \%$ & 4.33 \\
\hline \multicolumn{2}{|l|}{ Average } & $40 \%$ & $53.32 \%$ & $33.3 \%$ & $0 \%$ & $0 \%$ & 4.33 \\
\hline \multicolumn{7}{|l|}{$\begin{array}{l}\text { Mean } \\
(\max 5.0)\end{array}$} & $86.66 \%$ \\
\hline
\end{tabular}

The key question analysed within this research focused towards 'what waste do lean production practices eradicates within your organisation'. The results from this analysis provided a mean of $86.6 \%$ from the respondents that indicated the contribution of this criterion relatively high, and $40 \%$ of were 'strongly agree', 53.32\% were 'agree' and 33.3\% were 'undecided'. None of the respondents answered towards 'strongly disagree' or 'disagree' within their responses, hence providing the researchers that VSM had a positive impact towards their performance similar to the other literature evidence indicated within their studies (Rocha-Lona et al., 2013; Goriwondo et al., 2011).

\section{JIT}

As shown in Table VII that indicates the mean of JIT criteria factors at $85.88 \%$ as relatively high. There were a higher proportion of respondents strongly agreeing and agreeing to waste reduction and reduction of manufacturing costs, which was justified from literature studies (Kanyanya, 2013) that stated on using JIT within an organisation helps towards reduction of production costs and inventory levels, in turn reducing the customer query.

Table VII. Frequency Analysis for Criterion JIT

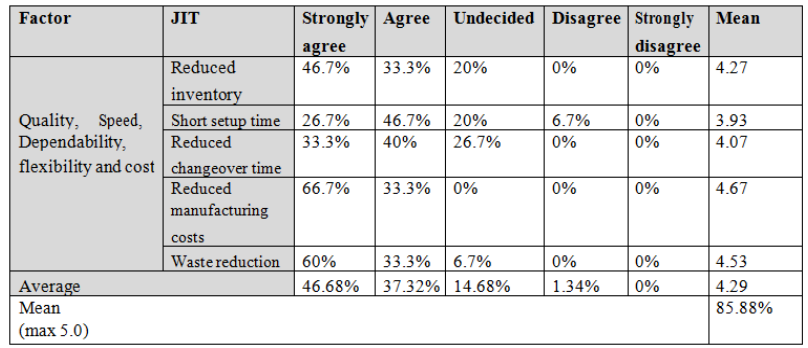

\section{Push and pull production}

As shown in Table VIII for frequency analysis of the push and pull production, the mean was $81.8 \%$ from the respondents that indicated that the contribution of this particular criterion was relatively high, and $66.7 \%$ 'strongly agreed' and '33.3\% response was 'agreed'. 
Table VIII. Frequency Analysis for Criterion Push-Pull

\begin{tabular}{|c|c|c|c|c|c|c|c|}
\hline Factor & \begin{tabular}{|l|}
$\begin{array}{l}\text { Push and pull } \\
\text { production }\end{array}$ \\
\end{tabular} & $\begin{array}{l}\text { Strongly } \\
\text { agree }\end{array}$ & \begin{tabular}{|l|} 
Agree \\
\end{tabular} & Undecided & Disagree & \begin{tabular}{|l|} 
Strongly \\
disagree
\end{tabular} & Mean \\
\hline \multirow{4}{*}{$\begin{array}{l}\text { Quality, speed, } \\
\text { dependability, } \\
\text { flexibility and cost }\end{array}$} & $\begin{array}{l}\text { Enhance quality } \\
\text { of output }\end{array}$ & $26.7 \%$ & $33.3 \%$ & $33.3 \%$ & $6.7 \%$ & $0 \%$ & 3.80 \\
\hline & $\begin{array}{ll}\begin{array}{l}\text { Decrease } \\
\text { time }\end{array} & \text { lead } \\
\end{array}$ & $26.7 \%$ & $46.7 \%$ & $26.6 \%$ & $0 \%$ & $0 \%$ & 4 \\
\hline & $\begin{array}{l}\text { Demand driven } \\
\text { production }\end{array}$ & $20 \%$ & \begin{tabular}{|l|l|}
$46.7 \%$ \\
\end{tabular} & $33.3 \%$ & $0 \%$ & $0 \%$ & 3.87 \\
\hline & $\begin{array}{l}\text { Production } \\
\text { smoothing }\end{array}$ & $66.7 \%$ & $33.3 \%$ & $0 \%$ & $0 \%$ & $0 \%$ & 4.67 \\
\hline \multicolumn{2}{|l|}{ Average } & $35.02 \%$ & $40 \%$ & $23.3 \%$ & $1.34 \%$ & $0 \%$ & 4.09 \\
\hline \multicolumn{7}{|l|}{$\begin{array}{l}\text { Mean } \\
(\max 5.0)\end{array}$} & $81.8 \%$ \\
\hline
\end{tabular}

\section{Pokayoke/Jidoka-Error Proofing/Automation}

Table VIII shows the results of the frequency analysis for Pokayoke/Automation where the mean was as high as $80 \%$.

Table IX. Frequency Analysis for Criterion Pokayoke/Jidoko

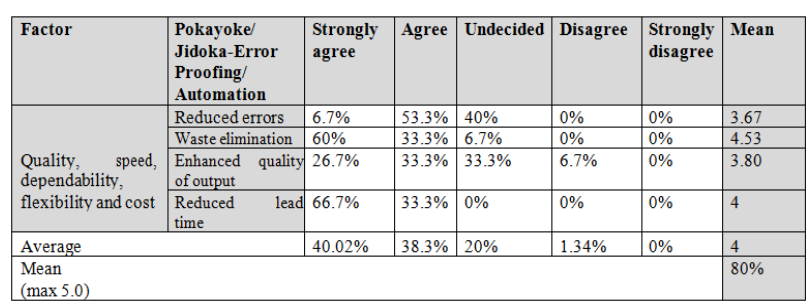

Hence with the high number of respondent agreeing to "Reduced errors", "Waste elimination", "Reduced lead time" and "Enhanced quality of output" agrees with previous research studies which stated that pokayoke helps to eliminate product defects by preventing, correcting or drawing attention to human errors (Dudek-Burlikowska and Szewieczek, 2009).

\section{Kanban - Information Transparency}

The analysis for "Kanban reducing cost of information processing" showed $66.7 \%$ responding with 'strongly agree' while the other $33.3 \%$ of the respondents 'agreed 'towards this statement.

Table X. Frequency Analysis for Kanban-Information

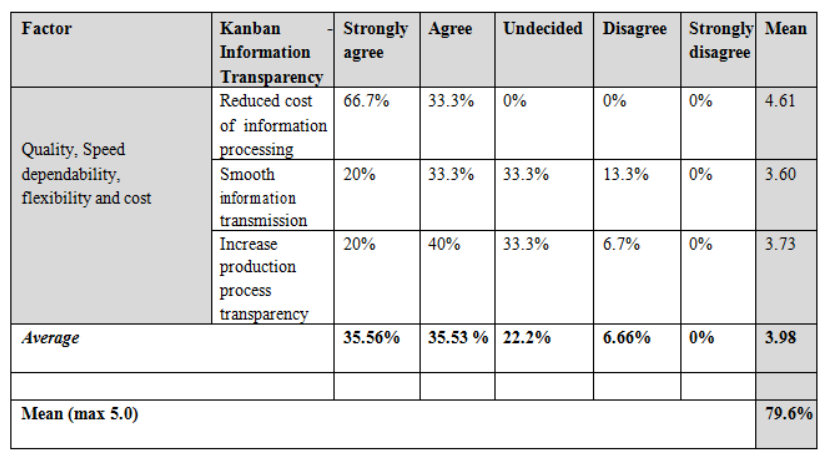

The mean from the responses was $79.6 \%$ which is relatively high. This means that respondents viewed this criterion as important because it contributes to overall production process. Surprisingly, only $13.3 \%$ of respondents disagreed to that smooth information transmission.

\section{Kaizen/Continuous Improvements}

Based on previous research studies, organisation use Kaizen to increase the quality of their product, eliminate waste, smoothing and reduction of errors during production processes (Kanyanya, 2013).

Table XI. Frequency Analysis for Kaizen/Continuous Improvement

\begin{tabular}{|l|l|l|l|l|l|l|l|}
\hline Factor & $\begin{array}{l}\text { Kaizen/ } \\
\text { Continuous } \\
\text { Improvements }\end{array}$ & $\begin{array}{l}\text { Strongly } \\
\text { Agree }\end{array}$ & Agree & Undecided & Disagree & $\begin{array}{l}\text { Strongly } \\
\text { disagree }\end{array}$ & Mean \\
\hline \multirow{3}{*}{$\begin{array}{l}\text { Quality, } \\
\text { Speed } \\
\text { dependability, } \\
\text { flexibility and cost }\end{array}$} & $\begin{array}{l}\text { Production } \\
\text { smoothing }\end{array}$ & $60 \%$ & $40 \%$ & $0 \%$ & $0 \%$ & $0 \%$ & 4.60 \\
\cline { 2 - 9 } & $\begin{array}{l}\text { Waste } \\
\text { elimination }\end{array}$ & $60 \%$ & $33.3 \%$ & $6.7 \%$ & $0 \%$ & $0 \%$ & 4.53 \\
\cline { 2 - 9 } & $\begin{array}{l}\text { Enhanced } \\
\text { quality of output }\end{array}$ & $66.7 \%$ & $33.3 \%$ & $0 \%$ & $0 \%$ & $0 \%$ & 4.67 \\
\cline { 2 - 8 } & Reduced errors & $6.7 \%$ & $53.3 \%$ & $40 \%$ & $0 \%$ & $0 \%$ & 3.64 \\
\hline Average & $\mathbf{4 8 . 3 5 \%}$ & $\mathbf{3 6 . 9 7} \%$ & $\mathbf{1 5 . 5 6} \%$ & $\mathbf{0} \%$ & $\mathbf{0} \%$ & $\mathbf{4 . 3 6}$ \\
\hline Mean (max 5.0) & & & & & & & \\
\hline
\end{tabular}

Therefore respondents were asked questions on the impact of Kaizen on their organisation. From Table XI, majority of the respondent strongly agree that kaizen helps in "production smoothing", "waste elimination", "error reduction" and "quality of output". The mean from the responses was $87.2 \%$ which is very high.

\section{Five (5) $\mathrm{S}$}

The result (Table XII) shows the frequency analysis for $5 \mathrm{~S}$ method, where the mean was $80 \%$ which indicated that the contribution of the criterion was high. Results showed that $66.7 \%$ 'strongly agreed' that $5 \mathrm{~S}$ methods helped organisations to "sort"; while $33.3 \%$ 'agreed' towards this, and majority of the respondents all agreed with this question. This further implied that $5 \mathrm{~S}$ method helped organisations to maintain discipline allowing the workplace to be self-explanatory, reducing defects and injuries within the workplace, thus reducing waste and higher production quality levels.

Table XII. Frequency Analysis for Criterion 5S

\begin{tabular}{|l|l|l|l|l|l|l|l|}
\hline Factor & Five (5) Ss & $\begin{array}{l}\text { Strongly } \\
\text { agree }\end{array}$ & Agree & Undecided & Disagree & $\begin{array}{l}\text { Strongly } \\
\text { disagree }\end{array}$ & Mean \\
\hline \multirow{2}{*}{$\begin{array}{l}\text { Quality, } \\
\text { Speed, } \\
\text { dependability, } \\
\text { flexibility and cost }\end{array}$} & Sort & $66.7 \%$ & $33.3 \%$ & $0 \%$ & $0 \%$ & $0 \%$ & 4.67 \\
\cline { 2 - 8 } & Set in order & $40 \%$ & $60 \%$ & $0 \%$ & $0 \%$ & $0 \%$ & 4.40 \\
\cline { 2 - 9 } & Shine & $0 \%$ & $100 \%$ & $0 \%$ & $0 \%$ & $0 \%$ & 4 \\
\cline { 2 - 8 } & Standardize & $0 \%$ & $73.3 \%$ & $33.3 \%$ & $0 \%$ & $0 \%$ & 3.73 \\
\cline { 2 - 8 } & Sustain & $6.7 \%$ & $6.7 \%$ & $86.7 \%$ & $0 \%$ & $0 \%$ & 3.20 \\
\hline Average & $22.66 \%$ & $54.66 \%$ & $24 \%$ & $0 \%$ & $0 \%$ & 4 \\
\hline $\begin{array}{l}\text { Mean } \\
\text { (max 5.0) }\end{array}$ & & & & & $\mathbf{8 0} \%$ \\
\hline
\end{tabular}

\subsection{Lean Production Practices Adoption in Company $\mathrm{X}$}

The participants of the study were asked to highlight the extent to which the implementation of the lean production practices has been impacting on the performance of their organisation. 
Table XIII. Frequency Analysis of Adoption of Lean Production Practices in company X (Shah et al., 2017)

\begin{tabular}{|l|c|c|c|c|c|c|}
\hline $\begin{array}{l}\text { To what extent has the Implementation } \\
\text { of Lean production practice impacted } \\
\text { on your organisations performance }\end{array}$ & $\begin{array}{c}\text { Very } \\
\text { large } \\
\text { extent }\end{array}$ & $\begin{array}{l}\text { Large } \\
\text { extent }\end{array}$ & $\begin{array}{c}\text { Moderate } \\
\text { extent }\end{array}$ & $\begin{array}{l}\text { Small } \\
\text { extent }\end{array}$ & $\begin{array}{l}\text { Very } \\
\text { small } \\
\text { extent }\end{array}$ & Mean \\
\hline Work in process reduction & $6.7 \%$ & $46.7 \%$ & $46.7 \%$ & $0 \%$ & $0 \%$ & 3.60 \\
\hline Inventory reduction & $0 \%$ & $40 \%$ & $53.3 \%$ & $6.7 \%$ & $0 \%$ & 3.33 \\
\hline Lead time reduction & $20 \%$ & $40 \%$ & $26.7 \%$ & $13.3 \%$ & $0 \%$ & 3.67 \\
\hline $\begin{array}{l}\text { Product and service quality } \\
\text { improvement }\end{array}$ & $20 \%$ & $60.7 \%$ & $13.3 \%$ & $0 \%$ & $0 \%$ & 4.07 \\
\hline $\begin{array}{l}\text { Improve material flow and through } \\
\text { put }\end{array}$ & $20 \%$ & $53.3 \%$ & $26.7 \%$ & $0 \%$ & $0 \%$ & 3.93 \\
\hline Waste reduction & $0 \%$ & $40 \%$ & $60 \%$ & $0 \%$ & $0 \%$ & 3.40 \\
\hline Manufacturing cost reduction & $0 \%$ & $40 \%$ & $53.3 \%$ & $6.7 \%$ & $0 \%$ & 3.33 \\
\hline Set up time reduction & $0 \%$ & $33.3 \%$ & $60 \%$ & $6.7 \%$ & $0 \%$ & 3.27 \\
\hline Profitability improvement & $26.7 \%$ & $60 \%$ & $13.3 \%$ & $0 \%$ & $0 \%$ & 4.13 \\
\hline Sales volume improvement & $0 \%$ & $26.7 \%$ & $60 \%$ & $13.3 \%$ & $0 \%$ & 3.13 \\
\hline Labour requirement reduction & $6.7 \%$ & $40 \%$ & $46.7 \%$ & $6.7 \%$ & $0 \%$ & 3.47 \\
\hline Productivity improvement & $20 \%$ & $66 \%$ & $20 \%$ & $0 \%$ & $0 \%$ & 4 \\
\hline \multicolumn{1}{|c|}{ Average } & $10.01 \%$ & $45.56 \%$ & $40 \%$ & 4.45 & $0 \%$ & 3.61 \\
& & & & & & \\
\hline \multicolumn{1}{|c|}{ Mean (max 5.0) } & \multicolumn{1}{|l}{} & & & & $72.2 \%$ \\
\hline
\end{tabular}

As shown from Table XIII, it is clear that the mean average of $3.61(\max 5.0)$ and that of $72.2 \%$ was high. Many of the respondents highlighted that the implementation of lean production practices impact has been the highest on the profitability performance of the organisation at 4.13. Similarly, higher proportion of respondents (mean of 4.07) identified that product and service quality improvement also had significant impact towards the implementation of lean production practices. Responses towards lead time reduction, work in progress reduction, improvement of material flow and throughput were all high that indicated the significant impacts of lean production practices been implemented within the organisation. The results demonstrates inventory reduction, manufacturing cost reduction, labour requirement reduction were average, which indicated the researchers that these were having moderate impacts towards the implementation of lean practices.

\subsection{Challenges of Lean Practices Implementation}

The research study identified the key challenges that the respondents faced while implementing lean practices within their environments and is as shown below in Table XIV. From the results and that of the analysis as shown in Table XIV that shows the challenges faced by company $\mathrm{x}$ while implementing lean practices, highlighting that the mean average of 3.72 was considerable high $(\max 5.0)$. This was because organisation's experienced the lack of commitment from the top management, continuous development including training and education was not sufficient, clarity of data and information accuracy, and employee's resistance to change and governmental regulation and policies.
Table XIV. Frequency Analysis of implementing lean Practices (Shah et al., 2017)

\begin{tabular}{|l|c|c|c|c|c|c|}
\hline $\begin{array}{l}\text { What challenges do Your } \\
\text { organisation face while } \\
\text { implementing Lean practices }\end{array}$ & $\begin{array}{c}\text { Strongly } \\
\text { Agree }\end{array}$ & Agree & Undecided & Disagree & $\begin{array}{c}\text { Strongly } \\
\text { Disagree }\end{array}$ & Mean \\
\hline $\begin{array}{l}\text { Lack of top management } \\
\text { commitment }\end{array}$ & $33.3 \%$ & $66.7 \%$ & $0 \%$ & $0 \%$ & $0 \%$ & $4.33 \%$ \\
\hline $\begin{array}{l}\text { Lack of continuous } \\
\text { education/ training }\end{array}$ & $33.3 \%$ & $66.7 \%$ & $0 \%$ & $0 \%$ & $0 \%$ & $4.33 \%$ \\
\hline $\begin{array}{l}\text { Poor information/ data } \\
\text { accuracy }\end{array}$ & $33.3 \%$ & $40 \%$ & $26.7 \%$ & $0 \%$ & $0 \%$ & $4.07 \%$ \\
\hline $\begin{array}{l}\text { Solely depending on } \\
\text { traditional system of work }\end{array}$ & $40 \%$ & $26.7 \%$ & $33.3 \%$ & $0 \%$ & $0 \%$ & $3.47 \%$ \\
\hline Financial constraints & $40 \%$ & $0 \%$ & $60 \%$ & $0 \%$ & $0 \%$ & $3.20 \%$ \\
\hline $\begin{array}{l}\text { Inexperienced technical staff } \\
\text { Lack of interface with } \\
\text { existing system }\end{array}$ & $13 \%$ & $60 \%$ & $0 \%$ & $40 \%$ & $0 \%$ & $3.20 \%$ \\
\hline Government policy & $46.7 \%$ & $20 \%$ & $6.7 \%$ & $26.7 \%$ & $0 \%$ & $3.87 \%$ \\
\hline $\begin{array}{l}\text { Employees resistance to } \\
\text { change }\end{array}$ & $46.7 \%$ & $13.3 \%$ & $26.7 \%$ & $13.3 \%$ & $0 \%$ & $3.93 \%$ \\
\hline Mean (max 5.0) & $31.81 \%$ & $34.04 \%$ & $21.49 \%$ & $12.59 \%$ & & 3.72 \\
\hline
\end{tabular}

The outcomes from the financial constraints, inexperienced technical staff and lack of interface with existing system infrastructure were solely dependent upon the traditional work practices (between 2.5 to 3.49 ).

The main aim of this research study was to investigate the impact of lean production practices on the performance of local baked foods supplier to university students. The results presented above indicate clearly that the organisation (baked food supplier) believes the different criteria factor as shown in table $\mathrm{V}$ can impact on their performance. It also shows to what extent the implementation of Lean production practice has impacted on the supplier and the challenges faced while implementing lean practices. There is also a strong triangulation between the end customers (i.e. students) and that of the supplier effectively providing products to the retailer (i.e. university cafe).

\section{Research Results and Discussions}

Having carried out the survey in the form of interview and questionnaires and presented the results graphically, the results from the research are discussed here. The research framework developed uses the questionnaires local baked goods suppliers (company X) and the analysis of the result from the factors in the framework that includes: Quality, Speed, Dependability, Flexibility, Cost, JIT, VSM, Automation, Kaizen, flow and push production, Pokayoke, Kanban and, 5S. It will also discuss the result showing the extent in which the implementation of Lean production practice has 
impacted on company $\mathrm{X}$ (i.e. supplier) performance and the challenges faced while implementing Lean practices.

\subsection{Impact of Lean Practices on Performance}

The analysis shows that lean production has impact on organisation performance by reducing and preventing quality defect thus allowing the improvement of quality. Furthermore, it was discovered that JIT has huge and positive impact on quality which confirm what Belekoukias et al. (2014) stated in their study that have significant impact on organisational performance. This implies JIT helps organisation to reduce their inventory thus tackling and eliminating all problems from their root cause. The analysis also shows that Kaizen contribute to the enhancement of quality and thus have a positive impact on quality; this is in line with what was stated in the literature (Imai, 2012). This means quality measure helps organisation to reduce defect, customer's complaints, scrap levels, warranty claims and thus satisfying their customers. The analysis also shows that Pokayoke helps to eliminate product defect thus having impact on quality. Finally, based on the analysis, 5S, Automation, Kanban and VSM also have impact on organisations performance; they improve the quality of product.

Table XV. Summary of key research concepts

\begin{tabular}{|c|c|}
\hline Measure & Analysis \\
\hline Speed & $\begin{array}{l}\text { - Lean production has impact on company X } \\
\text { performance in term of speed. } \\
\text { - With JIT, lead time, waste, setup time, cycle } \\
\text { time, and on time delivery are reduced. } \\
\text { - Automation has impact on company's } \\
\text { performance by helping them prevent defect, } \\
\text { reducing rework and scrap thus increasing } \\
\text { the speed of workers. } \\
\text { - Analysis showed that Kaizen and VSM have } \\
\text { impact on the performance of organisation. } \\
\text { - Analysis showed } 73.3 \% \text { of respondents } \\
\text { agreed that VSM reduces lead time } \\
\text { - Similarly, 5S method helps reducing defect } \\
\text { and injuries at the workplace thus having } \\
\text { impact on speed; which implies that since the } \\
\text { tools in the workplace are well organised, } \\
\text { workers can work at easy without asking } \\
\text { questions or looking for items. }\end{array}$ \\
\hline $\begin{array}{c}\text { Dependab } \\
\text { ility }\end{array}$ & $\begin{array}{l}\text { - Analysing the dependability measures proved } \\
\text { that lean production has impact on company } \\
\text { X performance. } \\
\text { - The findings showed JIT methods has strong } \\
\text { impact on dependability in term of on-time } \\
\text { delivery and inventory levels; corresponding } \\
\text { to previous findings JIT helped to increase } \\
\text { the delivery and response speeds. } \\
\text { - Findings showed } 60 \% \text { agreed that JIT } \\
\text { reduces waste which lead to on-time delivery } \\
\text { and reducing re-work of item; implying re- } \\
\text { work is waste; it delays and consumes time }\end{array}$ \\
\hline
\end{tabular}

\begin{tabular}{|c|c|}
\hline & $\begin{array}{l}\text { and may delay the delivery of finished goods. } \\
\text { - Automation also had an impact on } \\
\text { organisation performance by helping them } \\
\text { reduce defect quality and delivering the } \\
\text { product faster to customers. However, } \\
\text { Kaizen and VSM help in the smoothing of } \\
\text { the production levels. }\end{array}$ \\
\hline Flexibility & $\begin{array}{l}\text { - Research studies uses flexibility as a } \\
\text { performance measure when implementing } \\
\text { lean production practice. } \\
\text { - The findings from this study, identified JIT } \\
\text { method had huge impacts on flexibility } \\
\text { - It helped company X to reduce their } \\
\text { inventory; further implying that if inventory } \\
\text { is low, company X can easily change and } \\
\text { produce new or different product while } \\
\text { adapting to the new market developments. }\end{array}$ \\
\hline Cost & $\begin{array}{l}\text { - Research concluded that JIT methods had } \\
\text { strong impact on cost and the results found } \\
66.7 \% \text { of respondents 'strongly agreed' that } \\
\text { JIT reduces manufacturing cost. } \\
\text { - Previous literature studies confirmed that JIT } \\
\text { had positive effect on the success and } \\
\text { performance of organisations, implying the } \\
\text { contribution to increase companies' } \\
\text { profitability (Fullerton and Wempe, 2009). } \\
\text { - Automation also had impact on company X } \\
\text { performance as it prevented and reduced } \\
\text { quality defect, thus reducing the cost spent } \\
\text { on re-work, inspection, and warranty claim } \\
\text { or even after sales service. } \\
\text { - It enhances the rise of product sales due to its } \\
\text { reputation of organisations. } \\
\text { - From the analysis, methods such as 5S, } \\
\text { Kanban and kaizen also had an impact on } \\
\text { organisations performance; where Kaizen } \\
\text { methods helped organisation to reduced error } \\
\text { impacts on cost measures. }\end{array}$ \\
\hline
\end{tabular}

\subsection{Adoption of Lean Production Practices}

The analysis has shown that between $60 \%$ to $66 \%$ respondents believes that to a large extent productivity improvement, product and service quality improvement and also profitability improvement has significant impact on implementing Lean production practice. Again, interestingly enough, $60 \%$ of respondents believe that to a moderate extent waste reduction, sales volume improvement and set up time reduction has significant impact on implementing Lean production practice. However, $6.7 \%$ of respondents believe that to a small extent inventory reduction, manufacturing cost reduction, set up time reduction, labour requirement reduction has significant impact on implementing Lean production practice.

\subsection{Challenges of Implementing Lean Practices}

With regards to the challenges faced by organisations while implementing Lean practice, it appears that $66.7 \%$ of respondents agree that lack of 
top management commitment and lack of continuous education/training are among the major challenges they face while implementing Lean practices confirmed in previous studies (Sarhan and Fox, 2013). On the other hand, $46.7 \%$ of respondents strongly agree that Government policy and Employees resistance to change are also some of the challenges they face while implementing Lean practices. Interestingly enough, $60 \%$ of respondents agreed that financial constraint was a challenge they faced while implementing Lean practice (Abdullah et al., 2009). Organisation financial capability is a very critical factor, this is because they need money to train their employee, and get external consultants. However, based on the analysis, it is widely believed from organisation point of view that the implementation of lean production practice is not as easy as what people think. It basically requires extensive work in cooperation within as well as outside the organisation, although when fully implemented it will go a very long way in yielding long term benefits.

\section{Conclusions and Future Research}

This paper attempted to investigate the influence of lean practices on the performance of a food and beverage organisation referred to Company $\mathrm{X}$. it sought to analyse the level in which these practices have applied to the mentioned organisations and also the challenges they confront towards the journey of lean production practices adoption.

The research is designed based on descriptive methodology by conducting a questionnaire to the company as a main analysis tool. Most of the information was provided by the Company $\mathrm{X}$ as the producer, however, the university students were the respondents of the questionnaire and the university café manager was also interviewed. Analysis of the collected data were accomplished using the SPSS and Excel software and according to the analysis, the most utilised lean production tools applied by the company were JIT, VSM, 5S and Pokayoke (automation). In terms of improvement of quality, speed, dependability, flexibility and cost, JIT considered as the most influential factor towards enhancing the total performance of the company. Besides, Pokayoke seems to be a crucial element as well, since it can help them to eliminate the quality defects specifically on speed, quality, dependability and cost. 5S and Kaizen showed less significance on the total performance improvement. Using lean practices also enabled company for the faster and cheaper delivery and service, hence, reducing their inventory level. Nevertheless, at the time of lean implementation, Company $\mathrm{X}$ still needs to deal with the challenges regarding the gaps in the value added activities for the customer service. Besides, there are still some key motivation factors of lean practices implementation missing in the company including shortage of continuous personnel training, and their engagement, scarcity of senior management commitment, governmental policy alterations and financial limitations. Therefore, the continuous personnel training, effective teamwork and embracing the change will fulfil the vital factors of value, cost, delivery, flexibility.

According to the survey conducted to the local university students as the customers of baked products on campus, it was illustrated that they were not completely satisfied with the quality of the goods. Moreover, as evident from the interview of the café managers, it was stated that they consider product varieties, delivery time, price and reliability, before selecting their suppliers. Hence, this result is satisfactory as they consider the best strategies choosing their suppliers, and they also decide to carry on working with the same suppliers for better satisfaction of their customer expectations. This proves that the café is always relied to its suppliers for reliable deliveries and this can be enhanced through the further implementation of lean practices.

Lean practices are always considered as continuous process Company $\mathrm{X}$ needs to identify its customer needs in order to be able to create new design techniques to improve their production and gain the competitive advantage in the market. They also need to eliminate all the non-value added wastes such as activities that consume resource, time, space, and non-value added products or services; in addition to the overproduction waste that act as a major waste factor of the company and raises the inventory costs due to the lack of enough storage space. Again, the time period between the start and finish of production needs to be reduced. As the lean production is principally centred on the JIT, hence, Company $\mathrm{X}$ needs to consider the required amount of products based on the customer order. On the other hand, the appropriate association of supplier-customer is very beneficial in this case. Before the implementation of lean practices, there is a need for organisations to confirm that the workforce has received the appropriate information regarding the lean production and are well-trained. This is a very significant factor in lean transformation; since it provides the smooth knowledge delivery and skills required doing so. Besides, all the internal entities of the organisations are required to be properly informed regarding their roles and responsibilities towards shifting to lean and therefore, more tangible and intangible 
resources should be allocated towards the future company growth and improvement for better change management strategies towards the journey of lean production practices.

\section{References}

Abdullah, H. and Sinha, R. (2009), "Knowledge management and intellectual capital emerging perspectives", Critical factors for $\mathrm{KM}$ implementation: An L\&T, E\&C division case study. In Institute of Management Technology, Ghaziabad. pp. 53-71.

Anderson, R. Eriksson, H. Anderson, T. Eriksson, H. and Torstenson, H. (2006), "Similarities and differences between TQM, six sigma and Lean". The TQM Magazine, Vol. 18 No. 3, pp. 282-296.

Anvari, A. Zulkifli, N. and Yusuff. R. (2013), "A Dynamic Modeling to Measure Lean Performance within Lean Attributes", The International Journal of Advanced Manufacturing Technology, Vol. 66 No 5, pp. 663-677.

Arshinder, K. Kanda, A. and Deshmukh, G. (2011), "A Review on Supply Chain Coordination: Coordination Mechanisms, Managing Uncertainty and Research Directions", International Journal of Production Economics, Vol. 1 No.1, pp. 39-82

Bayou, E. and Korvin, A. (2008), "Measuring the Leanness of Manufacturing Systems - A Case Study of Ford Motor Company and General Motors", Journal of Engineering and Technology Management, Vol. 25 No. 4, pp. 287-304.

Belekoukias, I. Jose A. and Vikas K. (2014), "The Impact of Lean Methods and Tools on the Operational Performance of Manufacturing Organisations", International Journal of Production Research, Vol.52, No.18 pp. 53465366.

Berdie, D. and Anderson, J. (1986), "Questionnaires: design and use". Metuchen, N.J.: Scarecrow Press.

Bhasin, S. (2008), "Lean and performance measurement", Journal of Manufacturing Technology Management, Vol 19 No.5, pp. 670-84.

Bhasin, S. (2012), "Performance of Lean in Large Organisations", Journal of Manufacturing Systems, Vol. 31, No. 3, pp. 349-357.

Bicheno, J. (2007), The New Lean Toolbox, Piscie, London.
Boaden, R.J. (1997), "What is total quality management... and does it matter?", Total Quality Management, Vol. 8 No. 4, pp. 153-71.

Bortolotti, T. Danese, P. and Romano, P. (2013), "Assessing the Impact of Just-in-time on Operational Performance at Varying Degrees of Repetitiveness", International Journal of Production Research, Vol. 51 No. 4, pp. 11171130.

Carreira, B. (2005), Lean manufacturing that works: Powerful tools for dramatically reducing waste and maximizing profits. New York: AMACOM Div American Mgmt Assn.

Carson, D. Dilmore, A. Perry, C. and Gronhaug, K. (2001), "Qualitative Marketing Research". London: Sage Publications Ltd.

Cua, O. McKone-Sweet, E. and Schroeder, G. (2006), "Improving Performance through an Integrated Manufacturing Program", Quality Management Journal, Vol. 13 No. 3, pp. 45-60.

Dora, M. Kumar, M. Van Goubergen, D. Molnar A. and Gellync, X. (2013), "Operational performance and critical success factors of lean manufacturing in European food processing SMEs", Trends in Food Science \& Technology. Vol 31 No. 2, pp. 156 -164.

Dora, M. Van Goubergen, D, Kumar, M. Molnar, A. and Gellynck, X. (2014), "Application of lean practices in small and medium-sized food enterprises", British Food Journal, Vol. 116 No. 1, pp. 125-141.

Dudek-Burlikowska, M. and Szewieczek, D. (2009), "The Poka-Yoke method as an improving quality tool of operations in the process", Journal of Achievements in Materials and Manufacturing Engineering, Vol. 36 No. 1, pp. 95-102.

Emiliani, L. (2006), "Linking leader's beliefs to their behaviours and competencies".

Management Decision, Vol. 41, No. 9, pp. 2-6.

EuroCommerce. 2017, "Rising to the food waste challenge" [Online] Available at: http://www.eurocommerce.eu/media/134575/F ood\%20Waste\%20Brochure\%20-\%20final.pdf [Accessed: 12 July 2017].

Fanning, E. (2005), "Formatting a paper-based survey questionnaire: Best practices", Practical Assessment Research \& Evaluation, Vol. 10 No.12, pp. 2.

FDF. (2010), "UK Food and Drink Performance: Full Year 2009/2010. London, Food and Drink Federation". [Online] Available at http://ec.europa.eu/economyfinance/publication s/publicatio n15234_en.pdf [Accessed: 20 ${ }^{\text {th }}$ Nov 2016]. 
Forrester, P. Shimizu, U. Soriano-Meier, H. GarzaReyes, J. and Basso, L. (2010), "Lean Production, Market Share and Value Creation in the Agricultural Machinery Sector in Brazil", Journal of Manufacturing Technology Management, Vol. 21 No.7, pp. 853-871.

Fullerton, R.R., and W.F. Wempe. (2009), "Lean Manufacturing, Non-financial Performance Measures, and Financial Performance", International Journal of Operations \& Production Management, Vol. 29 No. 3, pp. 214-240.

Gembutsu. (2015), "Lean Manufacturing, Kaizen \& Toyota Production System TPS FAQ", [Online] Available at: http://www.gembutsu.com/lean_faq.html [Accessed: 24 Dec 2016].

Goriwondo, W. Mhlanga, S. and Marecha, (2011), "A. Use of the Value Stream Mapping Tool for Waste Reduction in Manufacturing. Case Study for Bread Manufacturing In Zimbabwe", Proceedings of the 2011 International Conference on Industrial Engineering and Operations Management, Vol. 1 No.1, pp. 236241.

Henderson, A., and Larco, L. (1999), Lean Transformation: How to Change Your Business into a Lean Enterprise, Richmond, VA: The Oaklea Press.

Hines, P. Holweg, M. and Rich, N. (2004), "Learning to evolve: A review of contemporary lean thinking", International Journal of Operations \& Production Management, Vol. 24 No.10, pp. 994-1011.

Hosseini Nasab, H. Aliheidari, T. and Khademi Zare, H. (2012), "Finding a probabilistic approach to analyse lean manufacturing", Journal of Cleaner Production, Vol. 29, pp. 73-81.

Imai, M. (2012), Gemba Kaizen: A Common Sense Approach to Continuous Improvement Strategy, 2nd ed. New York: McGrawHill Professional.

Kanyanya, O. (2013), Lean manufacturing practices and performance of Organisations listed at the Nairobi Securities Exchange, University of Nairobi.

Kaplan, R. and Norton, D.P. (2005), "The office of strategic management", Strategic Finance, Vol 87 No.4, pp. 56-60.

Khanchanapng, T. Prajogo, D. Sohal, A. Cooper, A. Yeung, A. and Cheng, T.C. (2014), "The unique and complementary effects of manufacturing technologies and lean practices on manufacturing operational performance",
International Journal of Production Economics, Vol 153, pp. 191-203.

Kumar, R. (2005), Research Methodology: a step by step guide for beginners, 2nd ed. London: Sage Publications Ltd.

Lewis, M.A. (2000), "Lean production and sustainable competitive advantage", International Journal of Operations \& Production Management, Vol. 20 No. 8, pp. 959-978.

Luning, P.A. Marcelis, and W.J. Jongen. W.M. (2002), Food quality management: A technomanagerial approach, Wageningen Pers.

Mahalik, N.P. and Nambiar, A.N. (2010), "Trends in food packaging and manufacturing systems and technology", Trends in Food Science \& Technology, Vol. 21 No. 3, pp. 117-128.

Malhotra N, and Birks D. (2003), Marketing Research: Applied Approach, Prentice-Hall, London.

Melton, T. (2005), "The Benefits of Lean Manufacturing: What Lean Thinking has to Offer the Process Industries", Chemical Engineering Research and Design, Vol. 83 No. 6, pp. 662-673.

Ohno, T. (1988), Toyota production system: beyond large-scale production, Tokyo: Productivity press.

Parker, S. (2003), "Longitudinal effects of Lean production on employee outcomes and the mediating role of work characteristics", Journal of Applied Psychology, Vol. 88 No. 4, pp. 620-34.

Pavnaskar, S. Gershenson, J. and Jambekar, A. (2003), "Classification Scheme for Lean Manufacturing Tools", International Journal of Production Research, Vol. 41 No. 13, pp. 3075-3090.

Pettersen, J. (2009), "Defining lean production: some conceptual and practical issues", The TQM Journal, Vol. 21 No. 2, pp. 127-142.

Rabiee, F. (2004), Focus-group interview and data analysis, Proceedings of Nutrition Society, Vol. 63, pp. 655-660.

Rahman, S. Laosirihongthong, T. and Sohal. A. (2010), "Impact of Lean Strategy on Operational Performance: A Study of Thai Manufacturing Companies", Journal of Manufacturing Technology Management, Vol. 21 No. 7, pp. 839-852.

Rocha-Lona, L. Garza-Reyes, J. and Kumar, V. (2013), Building Quality Management Systems: Selecting the Right Methods and Tools, Boca Raton, FL: Productivity Press, CRC Press, Taylor \& Francis. 
Romsdal, A., Kollberg, M., Dreyer, C., and Strandhagen, O. (2011), "Fresh food supply chains; characteristics and supply chain requirements", 18th international annual EurOMA conference. Cambridge, UK.

Sánchez, R., Cortijo, V. and Javed U. (2014), "Students' perceptions on Facebook for academic purposes", Computers \& Education, Vol. 70, pp. 138-149.

Sarhan, S. and Fox, A. (2013), "Barriers to Implementing Lean Construction in the UK Construction Industry", The Built \& Human Environment Review, Vol. 6 No. 1, pp. 1-17.

Sayed, H. (2013), "Supply Chain Key Performance Indicators Analysis", International Journal of Application or Innovation in Engineering \& Management, Vol. 2 No. 1, pp. 201-210.

Shah, R. and Ward, P. (2007), "Defining and developing measures of Lean production", Journal of Operations Management, Vol. 25 No. 4, pp. 785-805.

Shah, S. Naghi Ganji, E. and Coutroubis, A. (2017), "Lean production practices to enhance organisational performance", submitted to the WSEAS International Conference on Circuits, Systems, Communications and Computers, July 2017, Crete, Greece.

Spear, S. (1999), "The Toyota Production System: An example of managing complex social/technical systems", Ph.D. dissertation, Harvard Business School, Boston, MA.

Sugimori, Y. Kusunoki, K. Cho, F. and Uchikawa, S. (1977), "Toyota production system and Kanban system Materialization of just-in-time and respect-for-human system", International Journal of Production Research, Vol.15 No. 6, pp. 553-564.

Taj, S. and Morosan, C. (2011), "The Impact of Lean Operations on the Chinese Manufacturing Performance", Journal of Manufacturing Technology Management, Vol. 22 No. 2, pp. 223-240.

Vinodh, S. and Vimal, K. (2012), "Thirty Criteria Based Leanness Assessment Using Fuzzy Logic Approach", The International Journal of Advanced Manufacturing Technology, Vol. 60 No. 9-12, pp. 1185-1195.

Webb, T. (2010), "Most of what you need to know about Food and Beverage Service Types" [Online] Available at http://www.hospitalityinfocentre.co.uk/Learnin g\%20Resources/Work books/F\&B\%20Service\%20Types.pdf [Accessed: Dec 2016]

Wheatley, M. (2005), "Think lean for the long term: IT can make the journey smoother, but not without corporate commitment", Manufacturing Business Technology, Vol. 23 No. 6, pp. $36-38$.

Womack, J. and Jones, D. (1996), Lean Thinking: Banish Waste and Create Wealth in Your Corporation, Simon \& Schuster, New York, USA.

Womack, P. Jones, D. and Roos, D. (1990), The machine that changed the World: The triumph of lean production, New York: Rawson Macmillan.

Womack, J. and Jones, D. (2006), Lean Thinking, Simon \& Schuster, New York, NY. 